\title{
VIRULENCE AND CYTOTOXICITY OF SEAFOOD BORNE Aeromonas hydrophila
}

\author{
Seethalakshmi Illanchezian, SathishKumar Jayaraman*, Muthu Saravanan Manoharan, Saritha Valsalam
}

Life Teck Research Centre, Vadapalani, Chennai - 600026, India.

Submitted: April 17, 2009; Returned to authors for corrections: April 23, 2010; Approved: May 13, 2010.

\begin{abstract}
The present study was conducted to determine the virulence and cytotoxicity of Aeromonas hydrophila strains isolated from seafood samples collected from 5 major fish markets in Chennai, Tamil Nadu, India. Among 73 A. hydrophila strains isolated from fish and shrimp samples, 86.3\% exhibited haemolysis, $78.1 \%$ produced slime, $98.63 \%$ produced protease and also demonstrated cytotoxicity on Vero cells. Cell shrinkage, detachment and rounding of Vero cells were recorded as cytotoxic changes. Only one strain did not show haemolysis, slime production, proteolytic activity and cytotoxicity on treatment with Vero cells. Positive correlation was observed between proteolytic activity and cytotoxicity irrespective of haemolytic activity of the strains. These results demonstrated the presence of wide spread, pathogenically characterized, cytotoxic seafood borne A. hydrophila in Chennai.
\end{abstract}

Key words: Aeromonas hydrophila; seafood; virulence; cytotoxicity; Vero cells

\section{INTRODUCTION}

Fish and fishery products are of great importance worldwide due to their nutritional value, clear health benefits and wholesome properties (5). Though seafood are nutritive, they are highly prone to contamination. They act as a vehicle for pathogenic bacteria naturally occurring in the aquatic environment referred as indigenous or derived from post harvest contamination (7) may lead to cause human morbidities and mortalities worldwide.

Aeromonads are more commonly isolated from wide variety of sources including seafood (21) and associated with economic loss in fish culture world wide. These bacteria are opportunistic pathogens though they are part of the normal intestinal micro flora of the healthy fish (25).

Aeromonas hydrophila inhabit a wide variety of sources and has been implicated in a variety of infections in humans such as gastroenteritis, wound infections, septicemia and occasionally others including urinary tract infection, meningitis, and peritonitis. A. hydrophila is capable of expressing a number of virulence factors such as haemolysin, aerolysin, cytotoxin, enterotoxin, cytotonic enterotoxin, endotoxin lipopolysaccharide, outer membrane proteins and enzymes such as proteases, lipases, DNases, elastase and gelatinase $(3,12,14)$. The increasing antibiotic resistance among them also causes health problems in human beings. These characteristics make it to be an emerging pathogen posing several threats to humans.

The prevalence and multiple antibiotic resistance of $A$. hydrophila in seafood samples of Chennai, Tamil Nadu, India have been reported (20). The present study was performed to determine the virulence and cytotoxicity of the Aeromonas hydrophila isolated from seafood samples.

*Corresponding Author. Mailing address: 16 / 60, Senthil Andavar Street, Dhanalakshmi Colony, Vadapalani, Chennai-600026, India.; Tel: +91 98402 84994.; E-mail: jsathishkumar85@gmail.com 


\section{MATERIALS AND METHODS}

\section{Collection of samples, Isolation and Identification of Aeromonas hydrophila}

The seafood (fish and shrimp) collected from 5 major fish markets in Chennai viz. Ambattur, Mylapore, Porur, Thirumangalam and Vadapalani were taken for analysis. The sample processing, isolation and multiple antibiotic resistance of A. hydrophila were reported in our previous paper (20).

\section{Haemolytic activity}

The haemolytic activity of the A. hydrophila isolates were determined by blood agar plate assay (2). Pattern of haemolysis around the colonies on blood agar plates containing $5 \%(\mathrm{v} / \mathrm{v})$ human blood were recorded after $24 \mathrm{hr}$ incubation at $37^{\circ} \mathrm{C}$.

\section{Congo red uptake}

A. hydrophila isolates were plated on the surface of Brain heart infusion agar (HiMedia) plates prepared with $0.8 \mathrm{gL}^{-1}$ Congo red and incubated at $37^{\circ} \mathrm{C}$ for $48 \mathrm{hr}$ and colonies were then examined for Congo red uptake (6). When examined under obliquely reflected light on a black background, colonies that took up the dye were opaque and various shades of orange; they were clearly darker than the surrounding medium, in contrast to colonies that did not take up the dye. Slime production was considered to be high whenever the colonies were bright orange or red; colonies that were pale orange were considered to have moderate/low slime production.

\section{Preparation of cell free supernatant}

A. hydrophila strains were cultured in $10 \mathrm{~mL}$ of Brain heart infusion broth (HiMedia) and incubated at $37^{\circ} \mathrm{C}$ for $18 \mathrm{hr}$. Supernatant was carefully collected after centrifugation at 8000 $\mathrm{rpm}$ for $5 \mathrm{~min}$ at $4^{\circ} \mathrm{C}$ and filtered using $0.45 \mu \mathrm{m}$ syringe filter (Pall Lifesciences, India).

\section{Protease assay}

The cell free filtrate (crude enzyme suspension) was assayed for protease activity (4) using 0.6\% Casein (HiMedia) in $0.05 \mathrm{M}$ Tris - $\mathrm{HCl}$ buffer $(\mathrm{pH} 7.6)$ as substrate. To $2 \mathrm{~mL}$ of the substrate, $1 \mathrm{~mL}$ of crude enzyme was added and kept at $35^{\circ} \mathrm{C}$ for $30 \mathrm{~min}$. Then the reaction was stopped with $2.5 \mathrm{~mL}$ of $0.44 \mathrm{M}$ Trichloroacetic acid (TCA). After $1 \mathrm{hr}$, the contents were centrifuged at $15000 \mathrm{rpm}$ for $10 \mathrm{~min}$ at $4^{\circ} \mathrm{C}$. To $2 \mathrm{~mL}$ of supernatant, alkaline copper reagent $(1 \mathrm{~mL})$ was added and kept for incubation (10 min). Then Folin's phenol reagent (100 $\mu \mathrm{L}$ ) was added and kept for $30 \mathrm{~min}$. The absorbance was read spectrophotometerically at $660 \mathrm{~nm}$. The test was performed in duplicates and the average was defined as enzyme activity, which liberated $1 \mu \mathrm{g}$ of tyrosine per $\mathrm{mL}$ of the reaction mixture per min under standard conditions.

\section{Cytotoxicity}

The Vero cells (African green monkey kidney cells) obtained from King Institute of Preventive Medicine, Chennai, India was used for the cytotoxicity analysis of A. hydrophila isolates. The Vero cells were grown in 96 well flat bottom microtitre plate (Falcon) in Eagle's Minimum Essential Medium (HiMedia) supplemented with $10 \%$ fetal bovine serum (Labmate) and antibiotics (HiMedia). The cell suspension $\left(10^{4}\right.$ cells / mL) was seeded in every well and incubated at $37{ }^{\circ} \mathrm{C}$ for $48 \mathrm{hr}$ in $5 \% \mathrm{CO}_{2}$ for the formation of confluent monolayer. The monolayer of cells in 96 well plate was exposed to the cell free filtrate and its dilutions. Cell control was maintained throughout the experiment. Cytotoxicity changes in cell free filtrate treated Vero cells were recorded at timely intervals of incubation.

\section{RESULTS}

A total of 73 A. hydrophila isolates were obtained from fish and shrimp samples collected from 5 different fish markets in Chennai, during the study period.

All the 73 strains of $A$. hydrophila showed variation in their haemolysis pattern as recorded in Table 1. About $42.4 \%(n=31)$, $43.8 \%(n=32)$ and $13.7 \%(n=10)$ of the isolates produced $\alpha, \beta$ and $\gamma$ - haemolysis respectively.

Slime production was determined by Congo red dye uptake for all the strains of $A$. hydrophila (Table 2.). The results were recorded after $48 \mathrm{hr}$ of incubation. Among 73 isolates, $78.1 \%$ of them produced slime. 
Table 1. Haemolytic activity of $A$. hydrophila isolates from seafood ( $\mathrm{n}=73$ )

\begin{tabular}{lcccc}
\hline \multirow{2}{*}{ Source } & \multirow{2}{*}{ No. of isolates } & \multicolumn{3}{c}{ Haemolytic activity (\%) } \\
\cline { 3 - 5 } & & $\boldsymbol{\alpha}$ & $\boldsymbol{\beta}$ & $\boldsymbol{\gamma}$ \\
\hline Fish & 52 & $46.15(24)$ & $40.38(21)$ & $13.46(7)$ \\
Shrimp & 21 & $33.33(7)$ & $52.38(11)$ & $14.28(3)$ \\
\hline Total & 73 & $42.4(31)$ & $43.8(32)$ & $13.7(10)$ \\
\hline
\end{tabular}

Table 2. Slime Production in A. hydrophila isolates from seafood $(\mathrm{n}=73)$

\begin{tabular}{lcc}
\hline Source & Number of isolates tested & \% of slime production \\
\hline Fish & 52 & $76.9(40)$ \\
Shrimp & 21 & $80.9(17)$ \\
Total & 73 & $78.1(57)$ \\
\hline
\end{tabular}

Proteolytic activity was determined for all the 73 strains of A. hydrophila. The maximum and minimum level of protease activity observed in fish isolates was $155.1 \mu \mathrm{g} \mathrm{mL}$ and $91.3 \mu \mathrm{g} \mathrm{mL}^{-1}$ respectively, likewise the level of protease activity observed in shrimp isolates was between $155.6 \mu \mathrm{g}$ $\mathrm{mL}^{-1}$ and $91.2 \mu \mathrm{g} \mathrm{mL}^{-1}$. Notably, the strain Ah F26 showed no protease activity. Among the $32 \beta$ - haemolytic isolates, 31 of them showed proteolytic activity $\geq 122.3 \mu \mathrm{g} \mathrm{mL} \mathrm{m}^{-1}$ and of the $41 \alpha$ and $\gamma$-haemolytic isolates, 29 (26 $\alpha$ and $3 \gamma$-haemolytic) of them showed proteolytic activity $\geq 108.5 \mu \mathrm{g} \mathrm{mL}^{-1}$ (Tables 3 and 4).
All the 73 A. hydrophila isolates were subjected to cytotoxicity analysis on Vero cells. Cell shrinkage, detachment and rounding were observed as cytotoxicity changes. Vacuolating effects on Vero cells started within $6 \mathrm{hr}$ of bacterial supernatant addition. Complete cell death was observed within $72 \mathrm{hr}$, with total detachment and destruction of the monolayer. The cytotoxicity on Vero cells was observed till 1:16 dilution of the isolates' cell free filtrate. The cytotoxic effect was not observed in 1:32 and further dilutions. The cell free filtrate of strain $A h$ F26 did not show cytotoxic effects on Vero cells.

Table 3. Proteolytic activity of $A$. hydrophila isolates from fish samples $(\mathrm{n}=52)$

\begin{tabular}{|c|c|c|c|c|c|}
\hline \multicolumn{2}{|c|}{$\alpha-$ Haemolytic $(n=24)$} & \multicolumn{2}{|c|}{$\beta$ - Haemolytic $(n=21)$} & \multicolumn{2}{|c|}{$\gamma$ - Haemolytic $(n=7)$} \\
\hline Strain & Protease activity $\left(\mu \mathrm{g} \mathrm{mL} \mathbf{~}^{-1}\right)$ & Strain & Protease activity $\left(\mu \mathrm{g} \mathrm{mL}^{-1}\right)$ & Strain & Protease activity $\left(\mu \mathrm{g} \mathrm{mL}^{-1}\right)$ \\
\hline$A h \mathrm{~F} 25$ & 91.3 & $A h \mathrm{~F} 43$ & 101.8 & $A h \mathrm{~F} 26$ & - \\
\hline$A h \mathrm{~F} 2$ & 101.2 & $A h \mathrm{~F} 3$ & 123.3 & $A h \mathrm{~F} 4$ & 94.1 \\
\hline$A h \mathrm{~F} 12$ & 105.3 & $A h \mathrm{~F} 17$ & 129.3 & $A h \mathrm{~F} 41$ & 92.6 \\
\hline$A h \mathrm{~F} 11$ & 105.4 & $A h \mathrm{~F} 22$ & 131.3 & $A h \mathrm{~F} 40$ & 101.1 \\
\hline$A h \mathrm{~F} 30$ & 108.5 & $A h \mathrm{~F} 50$ & 132.4 & $A h \mathrm{~F} 29$ & 104.6 \\
\hline Ah $\mathrm{F} 38$ & 110.3 & $A h \mathrm{~F} 19$ & 139 & $A h \mathrm{~F} 28$ & 114.7 \\
\hline$A h \mathrm{~F} 35$ & 112.1 & $A h \mathrm{~F} 15$ & 139.4 & $A h \mathrm{~F} 51$ & 140 \\
\hline$A h \mathrm{~F} 6$ & 114.2 & $A h \mathrm{~F} 48$ & 140.3 & & \\
\hline$A h \mathrm{~F} 21$ & 115.2 & $A h \mathrm{~F} 8$ & 141.1 & & \\
\hline$A h \mathrm{~F} 5$ & 115.4 & $A h \mathrm{~F} 37$ & 141.2 & & \\
\hline$A h \mathrm{~F} 33$ & 116.3 & Ah F10 & 144.3 & & \\
\hline$A h \mathrm{~F} 31$ & 116.6 & $A h \mathrm{~F} 14$ & 145.3 & & \\
\hline Ah $\mathrm{F} 13$ & 121.3 & $A h \mathrm{~F} 47$ & 149 & & \\
\hline$A h \mathrm{~F} 39$ & 121.4 & $A h \mathrm{~F} 42$ & 149.7 & & \\
\hline$A h \mathrm{~F} 9$ & 122 & Ah $\mathrm{F} 52$ & 149.7 & & \\
\hline Ah $\mathrm{F} 32$ & 122.3 & $A h \mathrm{~F} 24$ & 151.2 & & \\
\hline$A h \mathrm{~F} 7$ & 122.4 & $A h \mathrm{~F} 27$ & 151.3 & & \\
\hline$A h \mathrm{~F} 44$ & 122.9 & $A h \mathrm{~F} 18$ & 151.4 & & \\
\hline$A h \mathrm{~F} 1$ & 124.3 & $A h \mathrm{~F} 16$ & 151.5 & & \\
\hline$A h \mathrm{~F} 49$ & 125.3 & $A h \mathrm{~F} 36$ & 152.3 & & \\
\hline$A h \mathrm{~F} 20$ & 126.3 & $A h \mathrm{~F} 34$ & 155.1 & & \\
\hline$A h \mathrm{~F} 23$ & 131 & & & & \\
\hline$A h \mathrm{~F} 45$ & 131.2 & & & & \\
\hline$A h \mathrm{~F} 46$ & 144.9 & & & & \\
\hline
\end{tabular}


Table 4. Proteolytic activity of $A$. hydrophila isolates from shrimp samples $(\mathrm{n}=21)$

\begin{tabular}{|c|c|c|c|c|c|}
\hline \multicolumn{2}{|c|}{$\alpha-$ Haemolytic $(n=7)$} & \multicolumn{2}{|c|}{$\beta$ - Haemolytic (n =11) } & \multicolumn{2}{|c|}{$\gamma$ - Haemolytic $(n=3)$} \\
\hline Strain & Protease activity $\left(\mu \mathrm{g} \mathrm{mL}^{-1}\right)$ & Strain & Protease activity $\left.(\mu \mathrm{g} \mathrm{mL})^{-1}\right)$ & Strain & Protease activity $\left(\mu \mathrm{g} \mathrm{mL}^{-1}\right)$ \\
\hline$A h \mathrm{~S} 5$ & 91.2 & $A h \mathrm{~S} 13$ & 122.3 & $A h \mathrm{~S} 8$ & 92.6 \\
\hline$A h \mathrm{~S} 4$ & 114.9 & $A h \mathrm{~S} 3$ & 131.8 & Ah S19 & 93.2 \\
\hline Ah S12 & 116.6 & $A h \mathrm{~S} 16$ & 142.1 & Ah S11 & 108.5 \\
\hline$A h \mathrm{~S} 9$ & 125.3 & $A h \mathrm{~S} 1$ & 144 & & \\
\hline$A h \mathrm{~S} 20$ & 128 & $A h \mathrm{~S} 6$ & 144.9 & & \\
\hline$A h \mathrm{~S} 21$ & 130.2 & $A h \mathrm{~S} 14$ & 146.3 & & \\
\hline Ah $\mathrm{S} 10$ & 132.4 & $A h \mathrm{~S} 7$ & 149 & & \\
\hline & & $A h \mathrm{~S} 2$ & 149.7 & & \\
\hline & & $A h \mathrm{~S} 17$ & 152.3 & & \\
\hline & & $A h \mathrm{~S} 15$ & 155.1 & & \\
\hline & & $A h \mathrm{~S} 18$ & 155.6 & & \\
\hline
\end{tabular}

\section{DISCUSSION}

When analyzing the previous investigations $(8,13,20,24$, 26,), a considerable increase in prevalence of $A$. hydrophila in seafood was observed over the years. Moreover, $98.63 \%$ of the 73 isolates were observed to be multiple antibiotic resistant against 20 commercially available standard antibiotics (20).

The occurrences of haemolytic factors in aeromonads are widespread (10). Of the 52 A. hydrophila isolates from fish, 46.1, 40.3 and $13.4 \%$ of them exhibited $\alpha, \beta$ and $\gamma$ haemolytic activity respectively. Of the 21 A. hydrophila isolates from shrimp, 33.3, 52.3 and $14.2 \%$ showed $\alpha, \beta$ and $\gamma$ - haemolytic pattern respectively. In the present study, equal distribution of $\alpha$ and $\beta$ haemolytic activity was observed (Table 1) which is in contrary to the results of Palumbo et al. (18) who reported that all strains isolated from retail foods of animal origin were $\beta$ - haemolytic.

Slime is another type of virulence factor, which is a viscous glycoconjugate material, produced by most of the Gram negative bacteria. It is also helpful in the formation of biofilm. The slime is highly significant to the pathogenesis; it appears to inhibit the neutrophil, chemotaxis, phagocytosis and antimicrobial drugs (17). Among the 73 isolates of $A$. hydrophila, $76.9 \%$ in fish and 80.9 $\%$ in shrimp isolates were positive for slime production.

Proteases are thought to contribute to virulence of aeromonads in fish and other hosts (9). Considerable differences between the number, types and quantities of protease produced by Aeromonas have been reported and attributed to the strain variation, origin, incubation temperature or culture media (16). All the 73 isolates of A. hydrophila except $A h$ F26 have produced protease enzyme after $24 \mathrm{hr}$, but the amount of protease production varied depending on the strains and species diversity, which is in agreement with the findings of Abdullah et al. (1). Howard and Buckley (11) reported that both the proteolytic and haemolytic activity are interrelated. The results of the present study supported the work of Gonzalez-Serrano et al. (9) who documented that there is no relation between proteolytic and haemolytic activities.

Aeromonads produce a wide range of extracellular toxins and enzymes. The multiplicity of extracellular products has led to difficulty in characterizing these factors and to disagreement in the enteropathogenicity. Generally, cytotoxins damage the cell and may produce severe illness in humans. Among the 73 A. hydrophila isolates, $98.61 \%$ exhibited cytotoxicity on Vero cells. Cytotoxic effects on Vero cells started within $6 \mathrm{hr}$ of bacterial supernatant addition and were monitored till $72 \mathrm{hr}$ of incubation time. In this study, Cytotoxicity was produced in $98.07 \%$ and $100 \%$ of cell free culture filtrate of A. hydrophila isolates from fish and shrimp samples respectively. Other studies reported that $73 \%$ of the food isolates (15) and $100 \%$ of the clinical isolates produced cytotoxicity on Vero cells (23).

In the present study, the cell free filtrate of A. hydrophila had an impact on the integrity of Vero cells and might facilitate a more rapid translocation of bacteria through the cells in vivo. 
Snowden et al. (22) observed similar type of impact on integrity of the monolayers of Caco-2 cell lines. However, the increased ability of $A$. hydrophila isolates to adhere, vacuolate and destruct the Vero cells was in contrast to the previous studies $(19,27)$. This may be due to the reflection of geographic variation among the cytopathic ability of the isolates.

Interestingly a notable relation was found between the virulence factors and the cytotoxicity of the A. hydrophila isolates on Vero cells. Among the 31 isolates $(\beta$ - haemolytic and showing proteolytic activity $\geq 122.3 \mu \mathrm{g} \mathrm{mL}^{-1}$ ), 27 strains' cell free filtrate had significant impact on Vero cells; complete cell death was observed within $12 \mathrm{hr}$ of bacterial supernatant addition. About 20 strains of the 26 ( $\alpha$ - haemolytic and showing proteolytic activity $\geq 108.5 \mu \mathrm{g} \mathrm{mL}^{-1}$ ) isolates' cell free filtrate exhibited complete death of Vero cells within $15 \mathrm{hr}$ of bacterial supernatant addition. All the $3(\gamma-$ haemolytic and showing proteolytic activity $\geq 108.5 \mu \mathrm{g} \mathrm{mL}^{-1}$ ) isolates' cell free filtrate showed complete death of Vero cells within $15 \mathrm{hr}$ of bacterial supernatant addition. Rest of the strains showed variations in the time to produce complete cytotoxic effects on Vero cells. Notably, the isolate $A h$ F26 did not showed haemolytic activity, protease activity, slime production and also showed no cytotoxic effects on Vero cells. This isolate may be regarded as non-pathogenic.

The haemolytic pattern of the strains had no direct relation to the cytotoxic activities as observed in vitro but might play an important role in the pathogenesis of the organism in vivo. Proteolytic activity had direct relation with the cytotoxic activity irrespective of haemolytic activity of the strains. Even though the results showed some relationship between proteolysis and cytotoxic effects, there are other extracellular virulence factors that must be studied in relation to pathogenicity of A. hydrophila. These extracellular factors might have different expression or subject to the same genetic control. It is not unlikely that different virulence factors are important under different conditions. Thus we must not only characterize the different protein toxins, but also address the genetic regulation of transcription.

\section{CONCLUSION}

These results demonstrated the presence of wide spread, pathogenically characterized, multiple antibiotic resistant, cytotoxic seafood borne A. hydrophila in Chennai. The relation found between the haemolysis; proteolysis and cytotoxic activities must be further evaluated in relation to genetic control of other extracellular virulence factors, molecular mechanisms and network of these virulence factors in exhibiting the pathogenesis of A. hydrophila.

\section{REFERENCES}

1. Abdullah, A.I.; Hart, C.A.; Winstanley, C. (2003). Molecular characterization and distribution of virulence - associated genes amongst Aeromonas isolates from Libya. J Appl Microbiol. 95, 1001-1007.

2. Breneder, R.; Janda, J.M. (1987). Detection, quantification and stability of the $\beta$ - haemolysin of Aeromonas spp. J Med Microbiol 24, 247-251.

3. Castro-Escarpulli G.; Figueras, M.J.; Aguilera-Arreola, G.; Soler, L.; Fernandez- Rendon, E.; Aparicio, G.O.; Guarro, J.; Chacon, M.R. (2003). Characterization of Aeromonas species isolated from frozen fish intended for human consumption in Mexico. Int J Food Microbiol. 84 (1), 41-49.

4. Charney, J.; Tomarelli, R.M. (1947). A colorimetric method for the determination of the proteolytic activity of duodenal juice. J Biol Chem. 171, 501-505.

5. Darlington, L.G.; Stone, T.W. (2001). Antioxidants and fatty acids in the amelioration of rheumatoid arthritis and related disorders. Br J Nutr. 85, 251-269.

6. Freeman, D.J.; Falkiner, F.R.; Keane, C.T. (1989). New method for detection slime production by coagulase negative staphylococci. J Clin Pathol. 42, 872-874.

7. Gillespie, I.A.; Adak, G.K.; O’Brien, S.J.; Brett, M.M.; Bolton, F.J. (2001). General outbreaks of infectious intestinal disease associated with fish and shellfish, England and Wales, 1992-1999. Commun Dis Public Health. Vol 4 (2), 117-123.

8. Gonazalez, G.J.; Santos, J.A.; Gareia-Lopez, H.L.; Gonazalez, N.; Otero, A. (2001). Mesophilic Aeromonas in wild and aquacultured fresh water Fish. J Food Prot. 64, 687-691.

9. Gonzalez-Serrano, C.J.; Santos, J.A.; Garcia-Lopez, M.L.; Otero, A. (2002). Virulence markers in Aeromonas hydrophila and Aeromonas veronii biovar sobria isolates obtained from fresh water fish and from a diarrhoea case. J Appl Microbiol. 93 (3), 414-419.

10. Hickman-Brenner, F.W.; MacDonald, K.L.; Steigerwalt, A.G.; Fanning, G.R.; Brenner, D.J.; FarmerIII, J.J. (1987). Aeromonas veronii, a new orthinine decarboxilase-positive species that may cause diarrhea. J Clin Microbiol. 25, 900-906. 
11. Howard, S.P.; Buckley, J.T. (1985). Protein export by a gram-negative bacterium: production of aerolysin by Aeromonas hydrophila. $J$ Bacteriol. 161, 1118-1124.

12. Howard, S.P.; Mac Intyre, S.; Buckley, J.T. (1996). Toxins. In: Austin, B., Altwegg, M., Gosling, P.J., Joseph, S. (Eds.). The Genus Aeromonas. Wiley and Sons, Chrichester, UK, p. 267-286.

13. Hudson, J.A.; De Lacy, K.M. (1991). Incidence of motile aeromonads in New Zealand retail foods. J Food Prot. 54, 696-699.

14. Janda, J.M.; Abbot, S.L. (1996). Human pathogens. In: Austin, B., Altwegg, M., Gosling, P.J., Joseph, S. (Eds.), The Genus Aeromonas. Wiley and Sons, Chrichester, UK, p. 151-170.

15. Martins, L.M.; Marquez, R.F.; Yano, T. (2002). Incidence of toxic Aeromonas isolated from food and human infection. FEMS Immunol Med Microbiol. 32, 237-242.

16. Mateos, D.; Anguita, J.; Naharro, G.; Panlagua, C. (1993). Influence of growth temperature on the production of extracellular virulence factors and pathogenicity of environmental and human strains of Aeromonas hydrophila. J Appl Bateriol. 74, 111-118.

17. Merino, S.; Rubires, X.; Knochel, S.; Tomas, J.M. (1995). Emerging pathogens: Aeromonas spp. Int J Food Microbiol. 28, 157-168.

18. Palumbo, S.A.; Bencivengo, M.M.; Corral, F.D.; Williams, A.G.; Buchanan, R.L. (1989). Characterization of the Aeromonas hydrophila group isolated from retail foods of animal origin. J Clin Microbiol. 27, 854-859.

19. Sechi, L.A.; Deriu, A.; Falchi, M.P.; Fadda, G.; Zanetti, S. (2002) Distribution of virulence genes in Aeromonas spp. isolated from Sardinian waters and from patients with diarrhoea. J Appl Bateriol. 92, 221-227.

20. Seethalakshmi, I.; Jayalakshmi, S.; Subashkumar, R.; Swaminathan, P.;
Rajagopal, K. (2006). Occurrence of multiple antibiotic resistant Aeromonas hydrophila isolated from marketed fish and shrimp samples. Indian J Appl Microbiol. 6 (1), 79-87.

21. Snieszko, S.F.; Bullock, G.L. (1976). Disease of freshwater fishes caused by bacteria of the genera Aeromonas, Pseudomonas and Vibrio. FDL 40, USKI, FWS, p.10.

22. Snowden, L.; Wernbacher, L.; Stenzel, D.; Tucker, J.; McKay, D.; O'Brien, M.; Katouli, M. (2006). Prevalence of environmental Aeromonas in South East Queensland, Australia: a study of their interactions with human monolayer Caco-2 cells. J Appl Microbiol. 101 (4), 964-975.

23. Sridharan, G.; Balaji, V.; Jesudason, M.V. (2004). Cytotoxin testing of environmental Aeromonas spp. in Vero cell culture. Ind J Med Res. 119, $1-3$.

24. Thayumanavan, T.; Vivekanandhan, G.; Savithamani, K.; Subashkumar, R.; Lakshmanaperumalsamy, P. (2003). Incidence of haemolysin-positive and drug-resistant Aeromonas hydrophila in freshly caught finfish and prawns collected from major commercial fishes of Costal South India. FEMS Immunol Med Microbiol. 36, 41-45.

25. Trust, M.B.; Currie, B.R.; Buckley, J.T. (1974). Obligate anaerobic bacteria in the gastrointestinal microflora of the grass carp (Ctenopharyngodon idella), goldfish (Carassius auratus) and rainbow trout (Salmo gairdneri). J Fish Res Board Can. 36, 1174-1179.

26. Vivekanandhan, G.; Hatha, A.A.M.; Lakhmanaperumalsamy, P. (2005). Prevalence of Aeromonas hydrophila in fish and prawns from the seafood market of Coimbatore, South India. Food Microbiol. 22, 133-137.

27. Yadav, M.; Indira, G.; Ansary, A. (1992). Cytotoxin elaboration by Aeromonas hydrophila isolated from fish with epizootic ulcerative syndrome. J Fish Dis. 15, 183-189. 